Website: https://e-journal.iainsalatiga.ac.id/index.php/islah

\title{
Code-switching and Code Mixing on Vlog: A Sociolinguistics Study
}

\author{
Emma Asyirotul Umami ${ }^{1}$, Betari Irma Ghasani ${ }^{2 *}$ \\ Pondok Pesantren Edi Mancoro, IAIN Salatiga \\ betari.Irmaiainsalatiga.ac.id
}

\begin{abstract}
English)
This paper aims for identifying the type of codeswitching and codemixing found on the vlog and recognizing factors causing codeswitching and codemixing. The researchers take data from 14 vlogs of Nurul Taufik themed Jaamiah or Campus. Some steps done in doing the research including listening to the vlog, analysing, and reporting. The result shows that there are 20 data of codeswitching and 52 data of codemixing. All forms of codeswitching belong to extraneous in the form of sentences. Some factors causing code switching are including speakers, interlocutors, the presence of a third person and changes in the topic of discussion. In addition, the form of code mixing is extraneous codes in the form of words, phrases, baster, repetition of words, expressions, and clauses. The cause of codemixing is the speaker's desire to get the "right" expression, and the habits and relaxedness of the speech act participants in communicating.

Keywords: Sociolinguistics, code-switching, code-mixing, vlog
\end{abstract}

\section{Abstract (Indonesian)}

Penelitian ini bertujuan untuk (i) mengetahui bentuk alih kode dan campur kode yang ada dalam $v \log$ dan (ii) mengetahui faktor-faktor penyebab terjadinya alih kode dan campur kode. Peneliti mengambil data dari $v \log$ Nurul Taufik yang bertemakan Jaamiah atau kampus sejumlah 14 vlog. Penulis menggunakan metode simak bebas libas cakap untuk tahap pengumpulan data, kemudian dianalisis menggunakan metode padan translasional, dan metode padan pragmatis, dan hasil analisis disajikan dengan menggunakan metode informal. Berdasarkan hasil analisis dari 72 data ditemukan adalah: terdapat 20 data berupa alih kode, dan 52 data berupa campur kode. Seluruh bentuk alih kode adalah alih kode ekstren dalam bentuk kalimat. Faktor penyebab terjadinya alih kode adalah faktor penutur, lawan tutur, kehadiran orang ketiga dan perubahan topik pembahasan. Bentuk campur kode adalah campur kode ekstren yang berbentuk kata, frasa, baster, pengulangan kata, ungkapan, dan klausa. Penyebab terjadinya campur kode adalah adanya keinginan penutur untuk memperoleh ungkapan yang "pas", dan kebiasaan dan kesantaian peserta tindak tutur dalam berkomunikasi.

Kata Kunci : Sosiolinguistik, Alih Kode, Campur Kode, Vlog. 
Code-switching and Code Mixing on Vlog:... (Emma Asyirotul Umami \& Betari Irma Ghasani)

\section{INTRODUCTION}

As an interaction device, language is a "genetic" communication tool exist in human being. ${ }^{1}$

By mastering a language, a person can communicate for obtaining various information and knowledge through language.

In Indonesia, generally, people are familiar with three kind of languages including regional languages (performs each characteristic of each language), Indonesian languages (or Bahasa Indonesia) and foreign languages. Since Indonesian people can communicate using two or more languages, they are called as bilingualism. ${ }^{2}$

For bilingual speakers who speaks bilingual language, they are very sensitive to the differences in both languages as they know that one language can be used better than another. $^{3}$ They often code-switch or code-mix from one language to another, especially when the languages are both used in their daily life. ${ }^{4}$ Therefore, exploring bilingualism means also discussing about code-mixing and code switching. ${ }^{5}$

Although some sholars defines code-mixing and code switching as the same term ${ }^{6}$, some sociolinguist proposes different perspective in explaining those terms. Richard and Schmid define code-mixing as a mixing of two codes or languages without a change of topic, while code switching means a change by a speaker from one language to another one because the othe speaker uses different language. ${ }^{7}$

Apple explains that code switching is a shift in language use due to changing situation. ${ }^{8}$ Suandi argues that code-switching can be classified into several types depend on the perspective. ${ }^{9}$ There are six factors promoting code-switching including the speakers' factor, the interlocutor's factor, the presence of the third parties, the discourse changing, the sense of humor factor, and the prestige factor. ${ }^{10}$ The phenomenon can be exemplified when two

\footnotetext{
${ }^{1}$ I Nengah Suandi, Sosiolinguistik (Yogyakarta: Graha Ilmu, 2014).

${ }^{2}$ PWJ Nababan, Sosiolinguistik: Suatu Pengantar(Jakarta: Gramedia Pustaka Utama, 1993), 27.

${ }^{3}$ Qasim Obayes Al-Azzawi, Majid Mohammed Saadoon, and Hasan Hadi Mahdi, "Code Switching and Code Mixing: A Sociolinguistic Study of Senegalese International Students in Iraqi Colleges," Journal of University of Babylon 26, no. 3 (2017): 112-22.

${ }^{4}$ Roberto R. Heredia and Jeanette Altarriba, "Bilingual Language Mixing: Why Do Bilinguals Code-Switch," Current Directions in Psychological Science 10, no. 5 (2001): 164.

${ }^{5}$ Nababan, Sosiolinguistik: Suatu Pengantar, 6.

${ }^{6}$ Al-Azzawi, Saadoon, and Mahdi, "Code Switching and Code Mixing: A Sociolinguistic Study of Senegalese International Students in Iraqi Colleges."

${ }^{7}$ Jack C. Richards and Richard Schmidt, Longman Dictionary of Language Teaching \& Applied Linguistics (London: Pearson, 2010), 88.

${ }^{8}$ Abdul Chaer and Leonie Agustina, Sosiolinguistik: Perkenalan Awal (Jakarta: PT Rineka Cipta, 2004).

${ }^{9}$ Suandi, Sosiolinguistik, 135.

${ }^{10}$ Chaer and Agustina, Sosiolinguistik: Perkenalan Awal, 94-96.
} 
Indonesian student study in a foreign country and use their mother tongue in their communication. The situation shifts when their friend with different language come and join them. Therefore, they change their language.

In addition, when a speaker master more than one language, code-mixing can occur accidentaly. The speakers speak and mix Indonesian and Arabic language, for example, when two Indonesian students in Saudi Arabia meet. Nababan explains that code-mixing occurs when a speaker mixes two languages or a variety of languages without any demanding situations. $^{11}$

Suandi proposes some factors causing code-switch and code-mix including similarity of mother tongue, desire for getting "fit" expression, and speakers' habit in daily-life communication. $^{12}$ Furthermore, bilinguals code-switching and code-mixing is for compensating their lack of language proficiency as they do not know the languages completely. ${ }^{13}$ Therefore, as the matter of relaxation and habits, code-mix and code-switch happens. $^{14}$

There are several types of code switching and code-mixing. Hadi proposes three kinds including inter-sentential and intra-sentential (tag-switching). While inter-sentential code switching happens at sentence boundaries, intra-sentential code-switching occurs in the middle of a sentence with no interruption or hesitation. ${ }^{15}$ Furthermore, Suandi suggests three types of code-mixing including inner code mixing, outer code mixing and hybrid code mixing. ${ }^{16}$ Based on the linguistics elements involved, Warsiman divides code-mixing into element insertion in the form of words (language units than can stand alone), phrases (combination of two words), repetition of words (reduplications), baster (combining two different languages forming meaning), colllocations or idioms (group of words expressing different meaning), and clauses (groups of words consisting at least a subject and a predicate which is potential to be a sentence). ${ }^{17}$

Furthermore, the phenomena of code-mixing and code-switching are not only found in everyday life but also seen in media as well as virtual worlds including social media. In social

\footnotetext{
${ }^{11}$ Nababan, Sosiolinguistik: Suatu Pengantar, 32.

${ }^{12}$ Sarwiji Suwandi, Serbalinguistik (Surakarta: Universitas Sebelas Maret, 2008), 95.

${ }^{13}$ Heredia and Altarriba, "Bilingual Language Mixing: Why Do Bilinguals Code-Switch."

${ }^{14}$ Nababan, Sosiolinguistik: Suatu Pengantar, 32.

${ }^{15}$ Al-Azzawi, Saadoon, and Mahdi, "Code Switching and Code Mixing: A Sociolinguistic Study of Senegalese International Students in Iraqi Colleges."

${ }^{16}$ Suandi, Sosiolinguistik, 140.

${ }^{17}$ Warsiman, Sosiolinguistik: Teori Dan Aplikasi Dalam Pembelajaran (Malang: UB Press, 2014), 97-98.
} 
media, people are not limited by time or distance for interacting and communicating to others. ${ }^{18}$ One social media which plays a significant role nowadays in entertainment industry is Youtube. ${ }^{19}$ As an online video repository in which any digital video file can be stored free of charge ${ }^{20}$, youtube ranked as the third most popular social media with hundreds of millions of users around the world. ${ }^{21}$

As a platform for sharing video, another trend arises recently called vlog. Vlog (video blog) is a record of your thoughts, opinions, or experiences that you film and publish on the internet. ${ }^{22}$ In recent years, vlogs have gained much attention worldwide and brought a new revolution in multimedia usage. ${ }^{23}$

Several studies done exploring youtube show significant result. Examining youtube for her writing class, Styati suggests that Youtube helps the students in writing performance. ${ }^{24}$ Combining code-mixing and vlog, Aini suggest that insertion code-mixing in English promotes some unpopular word. $^{25}$

As mentioned above, there are several studies conducted in exploring vlogs. However, investigating code-switching and code-mixing in Arabic vlogs in still limited. Therefore, this study is important to be done. In this study, the researchers explore code-switching and code-mixing in an Indonesian vlogger named Nurul Taufik. He is a student studying in Medina. Through his vlogs, he shares his experiences in Medina by using Arabic, English, and Indonesian. By using Nurul Taufik's vlogs as the data, this paper aims to investigate the type of the code-switching and code-mixing performed by him in his vlogs.

\footnotetext{
${ }^{18}$ Mariana Martinho, Marta Pinto, and Yuliya Kuznetsova, "Scholars' Youtube Channels: Content Analysis of Educational Video," Internet LLatent Corpus JournaL 2, no. 2 (2012).

${ }^{19}$ Margareth Holland, "No Title," Elon Journal of Undergraduate Research in Communication 7, no. 1 (2016).

${ }^{20}$ Jon Watkins and Michael Wilkins, "Using Youtube in the EFL Classroom," Language Education in Asia 2, no. 1 (2011).

${ }^{21}$ Martinho, Pinto, and Kuznetsova, "Scholars' Youtube Channels: Content Analysis of Educational Video."

${ }^{22}$ Cambridge Dictionary, “Online Cambridge Dic,” accessed March 25, 2021, https://dictionary.cambridge.org/dictionary.

${ }^{23}$ Wen Gao et al., "Vlogging: A Survey of Videoblogging Technology on the Web," ACM Computing Surveys 42, no. 4 (2010).

${ }^{24}$ Erlik Widiyani Styati, "Effect of Youtube Videos and Pictures on EFL Students'Writing Performance," Dinamika Ilmu 16, no. 2 (2016).

${ }^{25}$ Irhayatul Aini, “Code Mixing in Suhay Salim Beauty Vlogger,” Language Horizon 07, no. 1 (2019).
} 


\section{METODOLOGI}

This research is a qualitative research since it does not use any statistical procedures. As the nature of the data, qualitative research is a type of research producing findings without any statistical procedures. ${ }^{26}$ The data collected is not in the form of numbers, but words.

The data source in this research is Nurul Taufik's vlog. ${ }^{27}$ Using 14 vlogs, the researchers explore vlogs with Jami'ah theme since it helps readers in mastering Arabic vocabulary in the Jami'ah environment. These data belong to qualitative data since they contain information from a small number of individuals. ${ }^{28}$ Furthermore, the qualitative data chosen belong to audiovisual materials ${ }^{29}$ since it contains sounds which help researcher in understanding the research. ${ }^{30}$

In this research, the researchers did some stages that are explained further in the following description,

a. Collecting data

In collecting the data, the writer implemented listening method wih simak bebas libat cakap (SBLC) technique. SBLC is a technique in which the researcher does not directly involved in the conversation, but the researcher observe the conversation fully. ${ }^{31}$

In this stage, the researchers did several steps. At first, the researchers observe the vlogs and classifying it based on the theme. The classification made the researcher easier in choosing the vlogs with campus-themed or Jämi'ah. After getting the vlogs with campusthemed or Jämi'ah, the researchers listened several times and transcribed the vlogs by themselves simultaneously. By transcribing the vlogs, it is expected that the researcher could get flow of information contained on the vlogs.

After the transcription is complete, the researchers read the transcript one by one several times and highlight the code-mixing and code-switching found in the text. After finding the code-mixing and code-switching in the text, the researchers did the next step, analysis. The analysis step is explained further in the following description.

\footnotetext{
${ }^{26}$ Rasimin, Metodologi Penelitian: Pendekatan Praktis Kualitatif(Yogyakarta: Mitra Cendikia, 2018), 111.

${ }^{27}$ Nurul Taufik, “Jami'ah,” n.d., https:/www.youtube.com/channel/UC1P9JHveH1hsBiXL1CutdFg.

${ }^{28}$ John W Creswell, Educational Research: Planning, Conducting, and Evaluating Quantitative and Qualitative Research, 2012, 205, http://library1.nida.ac.th/termpaper6/sd/2554/19755.pdf.

${ }^{29}$ Betari Irma Ghasani and Ahmad Sofwan, “Appraisal and Speech Structure of Contestants' Speeches in Speech Contest of ESA WEEK Competition,” English Education Journal 7, no. 2 (2017): 151.

${ }^{30}$ Creswell, Educational Research: Planning, Conducting, and Evaluating Quantitative and Qualitative Research, 206.

${ }^{31}$ Sudaryanto, Metode Dan Aneka Teknik Analisis Bahasa (Yogyakarta: Sanata Dharma University Press, 2015), 203.
} 


\section{b. Analysing data}

The method used to analyze the data is metode padan. According to Sudaryanto, metode padan is a method whose determinants are external and independent of the language (langue) in question. Metode padan can be divided into five sub-types based on the type of determinant. $^{32}$ The five sub-types are referential method, phonetic-articulatory method, translational method, ortographic method, and pragmatic method. ${ }^{33}$ Metode padan used in this study is the translational, and pragmatic method.

The translational sub-type of metode padan used another language as determining tool. This method is used in this study to identify linguistic units and definitions in Indonesian and foreign language such as Arabic in the context of code switching and code mixing in Nurul Taufik's YouTube Videos. The pragmatic sub-type of metode padan used interlocutor as determining tool. ${ }^{34}$ This method is used to identify factors that cause code switching and code mixing in Nurul Taufik's YouTube videos.

There are several steps taken in analyzing data in this study. The first step is marking utterances that includes code switching and code mixing in a conversation. The next step is describing the utterances according to the context of the conversation. In the next step, the researcher will analyze the utterances according to the research problem. The researcher will then identify and group the data that has been given context and categorized based on whether the data belongs to words, phrases, clauses or sentences.

\section{c. Presentation of Data Analysis Results in Report Form}

The result of this study is presented in informal method. The informal method is a presentation formulated in ordinary words, mixed with technical terms. This study uses informal method with descriptive techniques, so that data obtained from analysis of code switching and code mixing can be described in detail through words.

\footnotetext{
${ }^{32}$ Sudaryanto, 15 .

${ }^{33}$ Sudaryanto, 18.

${ }^{34}$ Sudaryanto, 17.
} 


\section{DISCUSSION}

In linguistic terms, code switching is the use of variations of more than one language in one language event as a strategy to adapt to change of roles or situations. ${ }^{35}$ In this study, code switching is restricted to language code switching, namely code switching from Indonesian to Arabic, and from Arabic to Indonesian. The researcher marked Indonesian terms with ' $B I$ ' code, and the Arabic terms with ' $B A$ ' code.

Code mixing occurs when a speaker mixes two languages or a variety of languages without situations or circumstances that demand the mixing. Code mixing events occur only as a matter of habit and custom followed by the speaker. In this study, code mixing events occur in the form of external code mixing. The findings found in the text are described further on the following explanation.

\section{Code Switching Forms}

In this study, there were 20 utterances from Nurul Taufik's 14 vlogs which identified as a code-switching at various levels. These utterances are used in casual vlogs as it only recorded daily life with informal activities. There are 16 BI to BA code switching utterances and 4 BA to BI code-switching utterances. The following is an explanation of the form of code switching in Nurul Taufik's vlog, The researcher will also present a table of the percentage of data that has been obtained in the study

Table 1. Percentage of Code-Switching Forms

\begin{tabular}{ccc}
\hline Code Switching Forms & Frequency & Percentage \\
\hline Code Switching from BI to BA & 16 & $80 \%$ \\
Code Switching from BA to BI & 4 & $20 \%$ \\
\hline Total & 20 & $100 \%$ \\
\hline
\end{tabular}

Based on table 1, it can be inferred that there are 20 occurences of code-switching in the texts. The findings include Code-switching from $B I$ to $B A$ with 16 occurences $(80 \%)$ and code-switching from $B A$ to $B I$ with 4 occurences $(20 \%)$. The explanation of each finding is described further below.

This study emphasizes BI to BA code switching and identified 16 utterances. This form of code switching from Indonesian to Arabic occurs in vlogger and his friends who have the same mother tongue, namely Indonesian. They switched to Arabic because of their

\footnotetext{
${ }^{35}$ Harimurti Kridalaksana, No Title (Jakarta: Gramedia Pustaka Utama, 2011), 9.
} 
situation in arab country and their use of Arabic in daily basis. There are other situations which cause speakers to switch their language codes. The following is data obtained through this study.

\section{Data 1}

(Vlog Nurul Taufik, 7 Maret 2019,00:02:00) $)^{36}$

P1 : Dimana mencintai budaya ini harus kita tanamkan pada diri kita dimana Allah SWT mengatakan يايها الناس wahai manusia انّا خلقنكم sesungguhnya Kami menciptakan kalian itu dari

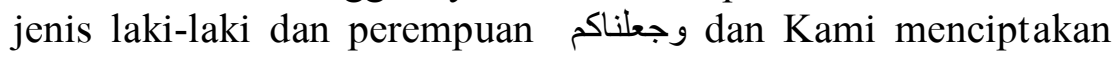
kalian وجعلناكم شعوبا و قبائل bermacam-macam bangsa dan suku انّ اكرمكم عند الله untuk saling mengenal وجعلناكم شعوبا و قبائل لتعارفوا sesungguhnya orang yang paling mulia disisi-Ku diantara kalian adalah orang yang palig bertakwa انّ اله عليم خبير Sesungguhnya Allah Maha Mengetahui dan Maha Mengenal

Notes:

P1 : Speaker.

Taufik, a vlogger from Indonesia who was attending college in Medina. He was attending an international cultural festival held by his campus at the Islamic University of Medina.

The data above is a conversation by speaker 1 in the opening of his vlog. Speaker 1 intended to explain a verse of the Qur'an which contains something about the suggestion to love the nation, tribe and culture. Speaker 1 read the verse and then switched to interpreting the verse into Indonesian, so that the vlog audience better understand the meaning contained in the verse. The code-switching that occurred is an external code-switching. The concept of speech component that occurs is a situation that refers to the genre, namely the delivery of a meaning from the Qur'anic verse. That is because, Speaker 1 had the intention to remind viewers of the meaning of a verse of the Qur'an, therefore Speaker 1 changed the language by switching from Arabic to Indonesian.

In this study, there are four occurences of code switching from Arabic to Indonesian. another example of code-switching found in the study is shown on the following example.

\footnotetext{
${ }^{36}$ Taufik, "Jami’ah.”
} 


\section{Data 17}

(Vlog Nurul Taufik, 22 Jan 2020, 00:02:00) ${ }^{37}$

P1 : Bismillahirrahmanirrahim, Asslamu'alaikumWarrahmatullahi Wabarakatuh. Alhamdulillah Wassholaatu Wassalam Waala' Rosulillahi Laa Haula Wa Laa Quwwata Illa Billahi. Amma Ba'du. Segala puji bagi Allah swt, yang telah memberikan kita nikmat yang agung yang sekarang kita rasakan. Kita bisa berkumpul di Madinah Munawwarah kotanya Rasulullah saw.

Notes:

P1 : Speaker.

Taufik, a vlogger from Indonesia who was attending college in Medina. He was starting the opening for the vlog entitled "baru tau begini suka duka dan cara kuliah di Yaman”.

Data 17 above contains a code-switching event that occurred in the words of Speaker 1 when opening his vlog by saying the opening phrases that is often used by Muslims. By marking it in the sentence "Bismillahirrahmanirrahim, Assalamu'alaikum Warrahmatullahi Wabarakatuh. Alhamdulillah Wassholaatu Wassalam Waala 'Rasulillahi Laa Haula Wa Laa Quwwata Illah Billahi. Amma Ba'du." Then, Speaker 1 changed the code-switching to Indonesian which was marked by the sentence "segala puji bagi Allah swt yang telah memberikan kita nikmat yang agung yang sekarang kita rasakan. Kita bisa berkumpul di Madinah Munawwarah kotanya Rasulullah saw."The type of code switching that occurred, which is external code switching due to code switching from BA to BI, is the concept of the speech component used in the code switching, because it has the intention in the opening vlog to greet the audience.

\section{Code Mixing Forms in Vlogs}

There are several forms of Arabic code mixing in Nurul Taufik's vlog that the researcher obtained from the results of listening, transcribing and identifying the data. The conversational data in this vlog that contains Arabic code mixing is classified as code mixing at the level of words, phrases, baster, repetition of words, expressions or idioms, and clauses. The form of code mixing at each level has a different amount.

\footnotetext{
${ }^{37}$ Taufik.
} 
Table. 2 Forms of code mixing

\begin{tabular}{lcc}
\hline \multicolumn{1}{c}{ Code mixing forms } & Frequency & Percentage \\
\hline Code mixing at the word level & 38 & $73 \%$ \\
Code mixing at the phrase level & 9 & $17 \%$ \\
Code mixing at the baster level & 2 & $4 \%$ \\
Code mixing at the word repetition level & 1 & $2 \%$ \\
Code mixing at the expression/idiom level & 1 & $2 \%$ \\
Code mixing at the clause level & 1 & $2 \%$ \\
\hline$\quad$ Total & 52 & $100 \%$ \\
\hline
\end{tabular}

Based on the text above, it maps out that there are 52 occurences of code-mixing found in the data including Code mixing at the word level with 38 occurences (73\%), Code mixing at the phrase level with 9 occurences (17\%), and Code mixing at the baster level with 2 occurences (4\%). Furthermore, for Code mixing at the word repetition level, Code mixing at the expression/idiom level, and Code mixing at the clause level are found with 1 occurrence (2\%). Each finding of code-mixing is explained further on the following description.

Code mixing at the word level is an event in a conversation where there is an insertion in the form of a word from one language to another. ${ }^{38}$ For example, in a conversation using Indonesian, the speaker or speech partner inserts a word of a foreign language or local language. In this study, however, the researcher restricted the analysis to the mixing of Arabic codes in Indonesian, as is the case in the following conversation excerpt from the analysis:

\section{Data 21}

(Vlog Nurul Taufik, 7 Maret 2019, 00:04:60) ) $^{39}$

P1 : Sekarang, ini lagi ada acara apa, tadz?

P2 : Ini nih acara mahrojaan namanya, mahrojaan itu seperti seni budaya antar bangsa.

\footnotetext{
${ }^{38}$ Suandi, Sosiolinguistik.

${ }^{39}$ Taufik, "Jami'ah."
} 
Notes:

P1 : Taufik, a vlogger from Indonesia who was attending college in Medina. He was attending an international cultural festival held by his campus at the Islamic University of Medina.

P2 : Islamic University of Madinah student from Indonesia who manned the Indonesian booth in the inrernational cultural festival held by the Islamic University of Madinah.

The conversation fragment contains code-mixing events at the word level because there are several Arabic words inserted by Speaker 1 and Speaker 2 in the conversation. In the conversation Speaker 1 inserts the word $\operatorname{tad} z$ which means ustadz in Indonesian means "teacher". The word has become a habit for Speaker 1 to call a friend who is regarded as having a higher status, and Speaker 1 has the intention to honor him. Then, Speaker 2 also inserted a word in the form of mahrojan which means "Festival". Speaker 2 was explaining about the ongoing activity, namely the international cultural festival called mahrojan. The concept of speech components used are setting, scene and participant.

The next finding is Code mixing at the phrase level. It is a condition when there is an insertion from one language to another in the form of a phrase in a conversation. ${ }^{40}$ In this study, researchers obtained fragments of conversations that contained insertions from Arabic in Indonesian in the form of phrases, such as the following conversation fragments:

\section{Data 49}

(Vlog Nurul Taufik, 7 Maret 2019, 00:05:30) (1 $^{41}$

P1 : Dibawa dari Indonesia. Kita minta bantuan sama ustadz-ustadz dirasat yang ada disini.

Notes:

P1 : Indonesian student who was studying at the Islamic University of Medina.

In the data 47 the researcher found code mixing at the phrase level. Which has been evidenced by the insertion of a phrase spoken by Speaker 1 ustadz-ustadz dirasat which means "Guru-guru pelajaran".

\footnotetext{
${ }^{40}$ Suandi, Sosiolinguistik.

${ }^{41}$ Taufik, "Jami’ah."
} 
The other findings relate to Code mixing at the baster level. It is a condition when there is a baster insertion in a conversation. ${ }^{42}$ Baster is the result of a combination of two different language elements, forming a meaning. In Nurul Taufik's vlog, he found code mixing in the form of baster with word patterns in Arabic and suffixes in Indonesian. The suffix is the clitic. Here are examples and explanations:

\section{Data 56}

(Vlog Nurul Taufik, 22 Jan 2020, 00:19:42) (3) $^{4}$

P1 : Dan yang ana kagumin dari Yaman tuh, selain dari keilmuannya ghiroh dari setiap thullaabnya itu kuat, kenceng. Jadi sunatullah sebagian ada yang biasa-biasa saja, sebagian lagi yang benar-benar jihadnya MasyaAllah.

\section{Notes:}

P1 : Muhammad Fadhilah, a student from Indonesia who was studying for a bachelor's degree at Darul Ulum University, Yemen

This fragment of the conversation includes code mixing at the baster level because Speaker 1 inserts words in Arabic and suffix in Indonesian. This is evidenced by the example of word thullaabnya, which consists of an Arabic word thullaab, which means students, and Indonesian genitive suffix nya. The word thullaabnya means their students. Another example of baster level code mixing is the word jihadnya, which consists of an Arabic word jihad, and Indonesian suffix nya. In Arabic jihad means struggle. The word jihadnya means their struggle. The two code-mixing at the baster level are words in Arabic and Indonesian suffix which can convey what Speaker 1 wants to say.

The next classification is Code mixing at the word repetition level. This type is a condition when in a conversation there is an insertion from one language to another in the form of word repetition. ${ }^{44}$ Repetition is the process of forming words by repeating its basic form. The resulting word is a repeat word. The following are excerpts of the conversation in the form of repetition of words:

\footnotetext{
${ }^{42}$ Suandi, Sosiolinguistik.

${ }^{43}$ Taufik, "Jami'ah."

${ }^{44}$ Suandi, Sosiolinguistik.
} 


\section{Data 57}

(Vlog Nurul Taufik, 7 Maret 2019, 00:05:30) ${ }^{45}$

P1 : Dibawa dari Indonesia. Kita minta bantuan sama ustadz-ustadz dirasat yang ada disini.

Notes:

P1 : Indonesian student who was studying at the Islamic University of Medina.

In the data 55, the researcher found code mixing at the word repetition level. Which has been evidenced by the insertion of repetition of words spoken by Speaker 1 ustadzustadz which means "teachers".

The next type is Code mixing at the expression or idiom level. This one relates to a condition when in a conversation there is an insertion from one language to another in the form of an expression or idiom. ${ }^{46}$ The researcher obtained fragments of conversations in Nurul Taufik's vlog which included code mixing at the expression or idiom level, as follows:

\section{Data 56}

(Vlog Nurul Taufik, 22 Jan 2020,00:27:03) ${ }^{47}$

P1 : Jadi silahkan itu kesadaran sendiri, kalau seandainya merasa bisa untuk ngikutin pelajaran ya tafadhol, terserah silahkan. Jadi kalau merasa dirinya belum mampu mendingn ikut takhasus di bahasa dulu.

\section{Notes:}

P1 : Muhammad Fadhilah, a student from Indonesia who was studying for a bachelor's degree at Darul Ulum University, Yemen

The code-mixing found in the conversation fragment is a form of code-mixing in expressions or idioms. This is evidenced by the insertion of Arabic expressions in Indonesian sentences. Speaker 1 inserts the expression tafadhol which means "please", the meaning of the speech is that invites others to join language institutions for those who are not able to speak Arabic.

\footnotetext{
45 Taufik, "Jami'ah."

${ }^{46}$ Suandi, Sosiolinguistik.

47 Taufik, “Jami'ah.”
} 
Code-switching and Code Mixing on Vlog:... (Emma Asyirotul Umami \& Betari Irma Ghasani)

\section{CONCLUSION}

Based on the results of the analysis of code switching and code mixing found in 14 vlogs with the theme of $J \bar{a} ' m i a h$, the following conclusions can be drawn:

1. The form of code switching and code mixing in the Jami'ah themed vlog consists of:

Researchers found as many as 20 code-switching occurences, with each type of code switching such as the BI to BA incident with 16 data, and the type of code switching from BA to BI with 4 data. All of them are in the form of external code switching. There are 52 code mixing occurrences, with 38 code mixing at the word level, 9 at phrase level, 2 at baster level, 1 at word repetition level, 1 at expression level, and 1 at the clause level code mixing. All of them are in the form of external code mixing.

2. Factors causing code switching and code mixing in vlogs.

Factors causing code switching include: (i) speakers, (ii) interlocutors, (iii) the presence of third party, and (iv) changes in the topic of discussion. Meanwhile, the factors causing code-mixing include: (i) the speaker's desire to obtain "right" expressions, and (ii) the habits and casualness of the speech act participants in communicating.

\section{REFERENCES}

Aini, Irhayatul. "Code Mixing in Suhay Salim Beauty Vlogger.” Language Horizon 07, no. 1 (2019).

Al-Azzawi, Qasim Obayes, Majid Mohammed Saadoon, and Hasan Hadi Mahdi. "Code Switching and Code Mixing: A Sociolinguistic Study of Senegalese International Students in Iraqi Colleges.” Journal of University of Babylon 26, no. 3 (2017): 112-22.

Cambridge Dictionary. "Online Cambridge Dic." Accessed March 25, 2021. https://dictionary.cambridge.org/dictionary.

Chaer, Abdul, and Leonie Agustina. Sosiolinguistik: Perkenalan Awal. Jakarta: PT Rineka Cipta, 2004.

Creswell, John W. Educational Research: Planning, Conducting, and Evaluating Quantitative and Qualitative Research, 2012.

http://library1.nida.ac.th/termpaper6/sd/2554/19755.pdf. 
Gao, Wen, Yonghong Tian, Tiejun Huang, and Qiang Yang. "Vlogging: A Survey of Videoblogging Technology on the Web.” ACM Computing Surveys 42, no. 4 (2010).

Ghasani, Betari Irma, and Ahmad Sofwan. “Appraisal and Speech Structure of Contestants' Speeches in Speech Contest of ESA WEEK Competition.” English Education Journal 7, no. 2 (2017): 152-59.

Heredia, Roberto R., and Jeanette Altarriba. "Bilingual Language Mixing: Why Do Bilinguals Code-Switch.” Current Directions in Psychological Science 10, no. 5 (2001): $164-72$.

Holland, Margareth. "No Title." Elon Journal of Undergraduate Research in Communication 7, no. 1 (2016).

Kridalaksana, Harimurti. No Title. Jakarta: Gramedia Pustaka Utama, 2011.

Martinho, Mariana, Marta Pinto, and Yuliya Kuznetsova. "Scholars' Youtube Channels: Content Analysis of Educational Video.” Internet LLatent Corpus JournaL 2, no. 2 (2012).

Nababan, PWJ. Sosiolinguistik: Suatu Pengantar. Jakarta: Gramedia Pustaka Utama, 1993.

Rasimin. Metodologi Penelitian: Pendekatan Praktis Kualitatif. Yogyakarta: Mitra Cendikia, 2018.

Richards, Jack C., and Richard Schmidt. Longman Dictionary of Language Teaching \& Applied Linguistics. London: Pearson, 2010.

Styati, Erlik Widiyani. "Effect of Youtube Videos and Pictures on EFL Students'Writing Performance.” Dinamika Ilmu 16, no. 2 (2016).

Suandi, I Nengah. Sosiolinguistik. Yogyakarta: Graha Ilmu, 2014.

Sudaryanto. Metode Dan Aneka Teknik Analisis Bahasa. Yogyakarta: Sanata Dharma University Press, 2015.

Suwandi, Sarwiji. Serbalinguistik. Surakarta: Universitas Sebelas Maret, 2008.

Taufik, Nurul. "Jami'ah," n.d. https://www.youtube.com/channel/UC1P9JHveH1hsBiXL1CutdFg.

Warsiman. Sosiolinguistik: Teori Dan Aplikasi Dalam Pembelajaran. Malang: UB Press, 2014.

Watkins, Jon, and Michael Wilkins. "Using Youtube in the EFL Classroom." Language Education in Asia 2, no. 1 (2011). 
Code-switching and Code Mixing on Vlog:... (Emma Asyirotul Umami \& Betari Irma Ghasani) 